\title{
ZIC1 wt Allele
}

National Cancer Institute

\section{Source}

National Cancer Institute. ZIC1 wt Allele. NCI Thesaurus. Code C75535.

Human ZIC1 wild-type allele is located in the vicinity of 3q24 and is approximately $7 \mathrm{~kb}$ in length. This allele, which encodes zinc finger protein ZIC 1, plays roles in regulation of transcription, development and differentiation of cerebellar granule cells. Mutations in this gene are associated with Dandy-Walker malformation. 